\title{
Miloš Hořejš \\ Relics of Nazi Architecture in the Czech Republic
}

\author{
Current Research, New Evidence, and Its Planned Integration into \\ a Geographic Information System (GIS)
}

Zusammenfassung: Nach dem ,Anschluss` Österreichs war die Tschechoslowakei das nächste Ziel der nationalsozialistischen Expansion nach Osten. Nach Einverleibung der Grenzgebiete im Oktober 1938 besetzte Nazi-Deutschland am 15. März 1939 die ,Rest-Tschechei‘ und kontrollierte das am selben Tag installierte sog. Protektorat Böhmen und Mähren. Der Aufsatz beschäftigt sich mit der Implementierung architektonischer und stadtplanerischer Konzepte in den besetzten Gebieten durch das NS-Regime, deren Ziel die räumliche und visuelle Germanisierung dieser Gebiete war. Die NSFührung beabsichtigte hier - wie auch in Deutschland selbst und in anderen besetzten Gebieten durch Architektur und Stadtplanung die deutsche Überlegenheit und Dominanz symbolträchtig zum Ausdruck zu bringen. Im Protektorat wurden architektonische und stadtplanerische Muster aus dem Deutschen Reich adaptiert, die den deutschen Herrschaftsanspruch deutlich machen sollten. Der Aufsatz stellt abschließend neue Wege vor, diese nur zum Teil auch umgesetzten Planungen mit Hilfe frei verfügbarer Karten in Form von Geoinformationssystemen (GIS) zu veranschaulichen.

Schlagwörter: Protektorat Böhmen und Mähren; Nationalsozialismus; Architektur; Stadtplanung; Geoinformationssysteme (GIS)

Abstract: After the Anschluss of Austria, Czechoslovakia was the next target of Nazi expansion to the east. Its border areas were initially occupied (October 1938) and then, on 15 March 1939, Nazi armies occupied the rest of the Czech Lands. A Protectorate of Bohemia and Moravia, fully under the control of the Nazi Reich, was created on the same day. This article deals with the implementation of architectonic and urbanistic concepts advocated by the Nazi regime in the occupied Czech Lands. The aim of Nazi-supported tendencies in architecture was to promote spatial and visual Germanisation of the occupied territories. The Nazi leadership was convinced that architecture and urbanism ought to function - both in Germany and in other occupied territories - as a symbol of German superiority and dominance. In the Protectorate, Nazi authorities clearly prioritised the implementation of architectonic and urbanistic patterns adopted from Germany. In the final part, the author briefly discusses plans for a new way of making these planned and actually implemented constructions more accessible in a specialised electronic map with specific expert content (geographical information system - GIS).

Keywords: Protectorate of Bohemia and Moravia; National Socialism; architecture; urbanism; geographical information system (GIS)

Dr. Miloš Hořejš, National Technical Museum, Kostelní 42, 17078 Prague 7, Czech Republic, milos. horejs@ntm.cz

Ә Open Access. (C) 2021 Miloš Hořejš, publiziert von De Gruyter. (๔) BY-Nc-ND Dieses Werk ist lizenziert unter der Creative Commons Attribution-NonCommercial-NoDerivatives 4.0 License.

https://doi.org/10.1515/9783110759891-005 


\section{Introduction}

Shortly after midnight, on 30 September 1938, representatives of France, Germany, Italy, and the United Kingdom signed the so-called Munich Agreement, which dictated that Czechoslovak border areas would be ceded to Germany, Hungary, and Poland. This was the first stage of the occupation of Czech Lands by Germany, which culminated with the invasion of Bohemia and Moravia on 15 March 1939 and declaration of the Protectorate of Bohemia and Moravia. It is interesting to note that the Munich Agreement, also known as the 'Munich Dictate', was signed in the city's Führerbau, a representative public building dedicated to the Führer, which was built in 1933-1937 based on a design by Paul Ludwig Troost (1878-1934). Troost was Adolf Hitler's favourite, and much promoted, architect. His neo-Classicist designs of the Führerbau and the Haus der Kunst in Munich, as well as the interiors of Hitler's office in the Old Chancery in Berlin, had significantly influenced the style of Nazi architecture. After Troost's death, the Führerbau was finished by Leonhard Gall (1884-1952), another important architect of the Nazi era and leader of Troost's bureau.

The choice of Munich for signing this agreement was no coincidence. It was closely linked to the establishment of the NSDAP and its rituals but, even more importantly, it was the main focus of Nazi aesthetics. It was a stage on which the regime displayed its artistic vision to the world. Munich's architecture and urban design were supposed to reflect Nazi ideology and dazzle Germans and foreigners alike with the grandeur of the Third Reich. After all, Hitler was convinced that art is inseparable from politics and a 'rejuvenation' of German art would lead to a renewal or renaissance of German politics. ${ }^{1}$ Hitler once said: 'Our buildings are our word carved in stone. ${ }^{2}$ The choice of location for the meeting of the representatives of signatories of the Munich Agreement was thus quite deliberate, and the building's architecture was intended to play a significant role during the abovementioned political negotiations. As it was, the agreement opened the door to Nazi expansion eastward which, among other things, facilitated the impact of Nazi aesthetics on the architecture of the Czech Lands.

The idea of a link between architecture and national identity was not, however, a Nazi invention. Architecture had, since at least mid-nineteenth century, often been employed as a visible and readily understandable symbol of national distinctiveness. It functioned as an expression of belonging to a particular vernacular or national culture. Folk architecture was studied as a part of efforts to determine the

1 Cf. Large, David Clay: Where Ghosts Walked. Munich's Road to the Third Reich. New York 1997, 231-267.

2 Cited after Kershaw, Ian: Popular Opinion and Political Dissent in the Third Reich. Bavaria 19331945. Oxford 2002, 159-172. 
limits of expansion of different ethnic groups, and elements of vernacular style increasingly featured in new buildings in towns and cities.

The use of architecture as an instrument of national identification culminated in the 1930s and the first half of the 1940s. ${ }^{3}$ In Bohemia and Moravia, architecture was used as a demonstration of national identity to the same extent by both the Czech and German national camps. ${ }^{4}$ Nazi occupation and, later, the war led to a marked imbalance in favour of Germans in the region. The long-term aim of aggressive German nationalism was to utterly annihilate and exterminate the Czech nation and to fully 'Germanise' the territory of Bohemia and Moravia. Indeed, a 'final solution of the Czech question' became an almost generally accepted principle on the German side, an attitude which was embodied in numerous large projects in the late 1930 s and early 1940 s.

German occupying forces were systematically creating conditions for implementing their long-term goals right from the start. In short, Nazi efforts to Germanise the territory of the Czech Lands were methodically promoted via a wide range of Germanising activities. It was an integral, inseparable part of German occupation policy. One could even speak of a kind of universal policy which, in the long term, touched upon almost all human activities: from education, culture, and language, through the social sector, all the way to many parts of the economy. Architecture and urbanism were very much part of this movement.

Architecture was seen as an important part of the occupational regime, both in its symbolic power and its practical application. This was largely determined by the fact that the senior Nazi leadership, especially Hitler, was interested in it. ${ }^{5}$ Generally speaking, German occupation authorities in the Protectorate did not ban theoretical discussions on the return to vernacular architecture, which were taking place in the Czech/Czechoslovak community of architects prior to 1939. Designs based on these debates were, however, implemented only in a handful of cases. ${ }^{6}$ In the Protec-

3 On contemporary development and functional categories, cf. Corbett, Harvey W.: 'Architecture'. In: Encyclopaedia Britannica. A New Survey of Universal Knowledge. Vol. 2. Chicago-LondonToronto 1947, 274-287, here 274-279. Further see also Curtis, William J. R.: Architektur im 20. Jahrhundert. Stuttgart 1989, 211-222 (Pt. 16: Totalitäre Kritik an der Moderne).

4 For the situation in Brno, cf. Kudělková, Lenka: Brněnská architektura a urbanismus v letech 1939-1942 [Architecture and Urbanism in Brno, 1939-1942]. In: Forum Brunense (2012), 53-72.

5 Cf. Spotts, Frederic: Hitler and the Power of Aesthetics. London 2001, 311-387.

6 For contemporary understanding of modern architecture among Czech architects, cf. Stefan, Oldřich: Nová architektura a její historický význam [The New Architecture and its Historical Significance]. In: Architektura 2 (1940), 140-146; Starý, Oldřich: Nová architektura obrazem současného života [The New Architecture as a Reflection of Contemporary Life]. In: Ibid., 133-137; Janák, Pavel: Čtyřicet let nové architektury za námi - pohled zpět [Forty Years of the New Architecture Behind Us: A Look Backwards]. In: Ibid., 129-132; Stefan, Oldřich: Úkoly naší budoucí architektury [The Tasks of Our Future Architecture]. In: Architektura 1 (1939), 109-114, and Tyl, Oldřich: Výstavba města projevem současného života [Construction of a City as a Manifestation of Contemporary Life]. In: Ibid., $104 \mathrm{f}$. For statistical overviews of realisations, cf. Stavební ruch [Construction Activities]. In: 
torate, which was in many respects seen as a periphery, Nazi decision makers clearly preferred architectonic and urbanistic patterns adopted from Germany. ${ }^{7}$ From the Nazi viewpoint, architecture and urbanism - understood in broader sense as a part of the Raumordnung - were supposed to function as a symbol and concrete reminder of German superiority and dominance. ${ }^{8}$ Architectural styles preferred by National Socialism - such as cities formed by Nazi planners, nature shaped by Nazi landscape designers - were regarded as part of a visible Germanisation (Germanisierung) or re-Germanisation (Regermanisierung) of the public domain. ${ }^{9}$ The goal of this effort was to indicate that the occupied cities and entire landscapes would serve other people in near future, and would be also spatially fully integrated into the Nazi empire.

Statistické zprávy 2/10-12 (1939), 202-209; Bytový komfort v našich novostavbách [Apartment Comforts in the Newbuilds]. In: Ibid. 4/9-10 (1941), 52 f.; S. V.: Bautätigkeit und Wohnungsmarkt. In: Ibid. 6/7 (1943), 254-256, and Š. L.: Die Bauindustrie im Jahre 1943. In: Ibid. 7/12 (1945), 332-335. 7 For the situation in Germany, cf. Düwel, Jörn; Gutschow, Niels (Ed.): Baukunst und Nationalsozialismus. Demonstration von Macht in Europa 1940-1943. Berlin 2015; Nordinger, Winfried (Ed.): Architektur und Verbrechen. Die Rolle der Architekten im Nationalsozialismus. Göttingen 2014; Bartetzko, Dieter: Illusionen in Stein. Stimmungsarchitektur im Nationalsozialismus. Berlin 2012; Kuo, Hsiu-Ling: Monumentality and Modernity in Hitler's Berlin. The North-South Axis of the Greater Berlin Plan. Pieterlen-Bern 2012; Litschauer, Maria T.: Architekturen des Nationalsozialismus. Die Bau- und Plantätigkeit im Kontext ideologisch fundierter Leitbilder und politischer Zielsetzungen am Beispiel der Region Waldviertel 1938-1945. Wien 2012; Straub, Jakob; Feucht, Jakob: Schatten der Macht. Architektur des Nationalsozialismus in Berlin. Berlin 2006; Harlender, Tilman; Pyta, Wolfram (Ed.): NS-Architektur. Macht und Symbolpolitik. Berlin 2010 (Kultur und Technik 19); Ellenbogen, Michael: Gigantische Visionen. Architektur und Hochtechnologie im Nationalsozialismus. Graz 2006; Porombzka, Stephan; Broder, Henryk M. (Ed.): Böse Orte. Stätten nationalsozialistischer Selbstdarstellung. Berlin 2006; Mittmann, Markus: Bauen im Nationalsozialismus. Braunschweig, die „Deutsche Siedlung“, und die „Mustersiedlung der Deutschen Arbeitsfront Braunschweig-Mascherode“. Ursprung - Gestaltung - Analyse. Hameln 2003; Cluet, Marc: L’architecture du IIIe Reich. Bern 1987; Nietzke-Senger, Christel: Verordnete Architektur. Architektur im Nationalsozialismus. Berlin 1984. For the situation in the occupied territories, cf. Holzschuh, Ingrid: 2015. Wien. Die Perle des Reiches. Planen für Hitler. Zürich 2015; eadem: Otto Strohmayr (19001945). Hitlers Architekt für die Neugestaltung der Stadt Salzburg im Nationalsozialismus. WienKöln-Weimar 2015; eadem: Wiener Stadtplanung im Nationalsozialismus von 1938 bis 1942. Das Neugestaltungsprojekt von Architekt Hanns Dustmann. Wien-Köln-Weimar 2011; Voigt, Wolfgang: Deutsche Architekten im Elsass 1940-1944. Planen und Bauen im annektierten Grenzland. Tübingen-Berlin 2012; Němec, Richard: Die Ökonomisierung des Raums. Planen und Bauen in Mittel- und Osteuropa unter den Nationalsozialisten 1938 bis 1945. Berlin 2020.

8 Cf. Kerrl, Hanns: Reichsplanung und Raumordnung. Berlin 1938; Meyer, Konrad: Raumforschung, eine Pflicht wissenschaftlicher Gemeinschaftsarbeit! Neudamm 1936.

9 Cf. Schultze, Joachim H.: Deutsche Siedlung. Raumordnung und Siedlungswesen im Reich und in den Kolonien. Stuttgart 1937. 


\section{Institutional and Professional Background}

Just two weeks after the German occupation of Bohemia and Moravia, on 30 March 1939, the Berlin headquarters of the Reich Office for Spatial Planning (Reichsstelle für Raumordnung, established in 1935, hereafter RfR) asked Konstantin von Neurath (1873-1956), the likely future Reich Protector - the head of the new German administration of the Protectorate - to establish an institute that would be in charge of spatial organisation of the Protectorate. ${ }^{10}$ The Berlin headquarters was led by Ernst Jarmer (1886-1945), a German lawyer from Lower Silesia, who was first appointed to the role in $1937 .{ }^{11}$ In 1940 , Jarmer clearly stated that, under National Socialism, spatial organisation offers a unique opportunity for implementing the main principles of the Reich's approach to spatial planning (Raumordnung). Furthermore, he added, it should be applied not only to the Sudeten German regions but also to the Protectorate, which was now included into the Reich. ${ }^{12}$ Jarmer demanded that a general department for spatial organisation be also established in the Protectorate, in parallel to that found in the Reich, and supposedly accompanied by a corresponding scientific institution. ${ }^{13}$ Jarmer presented his official position in his article Ordnung des deutschen Lebensraumes, which included an organisational chart and definitions of Reich planning versus regional planning. Sudeten German areas were understood as a separate administrative unit (Reichsstatthaltergebiet) within the Reich, while the Protectorate was to become an integral and permanent part of Reich planning. The Protector had apparently already created an Office for Regional Organisation. $^{14}$

As a result of the outbreak of the war and a subsequent shift of focus towards the armament industry, the RfR sought various ways of influencing the planning of

10 Bundesarchiv Berlin (BArch) R 113/411: Protocol of Wilhelm Fischer containing Jarmer's list of participants. 20.03.1939.

11 Ernst Jarmer graduated in Greifswald with a thesis entitled "Neugestaltung des Boden- und Kreditrechts". He thus seemed destined for a role in the Nazi Reich Office for Spatial Planning and was appointed by Reichsminister Hans Kerrl on 9 August 1935. It was also Kerrl who proposed him for the post of head of the ministerial department in April 1937. Cf. BArch R 113/1857 (Ernst Jarmer's appointment to the function, which includes numerous testimonies of participating offices) as well as Jarmer's biography (Ibid. Coll. NS 5-VI/17619. Archiv für publizistische Arbeit, 78).

12 Cf. Erlaß des Führers und Reichskanzlers über das Protektorat Böhmen und Mähren vom 16. März 1939. In: Reichsgesetzblatt. Teil 1. 16.03.1939 (Nr. 47), 485-488. For details on Sudeten Germans, cf. Brandes, Detlef: Die Sudetendeutschen im Krisenjahr 1938. München 2008. For contemporary argumentation, cf. Meyer, Hans: Der Sudetengau in der Raumordnung. Posen 1943.

13 Národní archiv (NA) Praha [National Archives Prague]. Coll. AMV-ST. Box 114. No 109-6-71: Jarmer's letter to K. H. Frank, 24.02.1940.

14 Cf. Jarmer, Ernst: Ordnung des deutschen Lebensraumes. In: Lammers, Hans; Pfundtner, Hans (Ed.): Die Verwaltungs-Akademie. Ein Handbuch für den Beamten im nationalsozialistischen Staat. Vol. 2: Der Aufbau des nationalsozialistischen Staates. Berlin 1940, 1-34. 
industrial towns in occupied eastern territories. ${ }^{15}$ Within the Office of the Reich Protector (Amt des Reichsprotektors), the group for spatial planning (Gruppe Raumordnung), headed by the ministerial counsellor Dr. Wilhelm Fischer (b. 1893), was particularly linked to the RfR. ${ }^{16}$ It was intended that the existing Czech Land Department and Planning Commission for the Capital City of Prague would be subordinated to the new structures. Jarmer visited Prague several times. His aim was to achieve a closer collaboration between the RfR and the Office of the Reichsprotektor regarding mutual authorisation of planning in the Protectorate and the Reich where the project at hand was pertinent to the interests of both. ${ }^{17}$

This process thus involved existing Protectorate institutions and legislation. For example, the State Regulation Committee, originally staffed only by Czech architects, was transformed by Protectorate government directive No. 48/1940 Coll. into a Planning Commission for the Capital City of Prague and its Surroundings (Planungskommission für die Hauptstadt Prag und Umgebung). Reinhold Niemeyer (1885-1959), a professor of architecture summoned from Germany to the German Technical University (Deutsche Technische Hochschule) in Prague, was appointed its head and Herman Wunderlich (1889-1981), assistant professor of architecture at the German Technical University and representative of 'local' Germans, became its first deputy director. ${ }^{18}$ Leading experts from the Reich were called for consultations to various locations in Prague and its wider surroundings, where new developments were planned. Through Niemeyer, the influence of the RfR significantly increased, because both Niemeyer and Fischer were frequent contributors to its journal Raumforschung und Raumordnung. ${ }^{19}$ Niemeyer was also the person who invited Albert Speer (1905-1981) to consult with his office on the further development of Prague. ${ }^{20}$ Another institution that influenced activities of the Planning Commission for Prague was the German Academy for Urban Development, Reich, and Land Planning (Deutsche Akademie für Städtebau, Reichs- und Landesplanung), also headed by Niemeyer.

15 Cf. Müller, Rolf-Dieter: Hitlers Ostkrieg und die deutsche Siedlungspolitik. Die Zusammenarbeit von Wehrmacht, Wirtschaft und SS. Frankfurt/M. 1991, 59.

16 On Fischer in more detail, cf. Hořejš, Miloš: Protektorátní Praha jako německé město. Nacistický urbanismus a Plánovací komise pro hlavní město Prahu [Prague During the Protectorate as a German Town, Nazi Urbanism and Planning Commission for the Capital City of Prague]. Praha 2013, 142.

17 Cf. NA Praha. Coll. AMV-ST. Box 114. No 109-6-71: Jarmer to K. H. Frank, 24.02.1940; ibid.: Fischer to von Burgsdorff concerning the organisation of the Office of the Reichsprotektor incl. a chart, 26.02.1940.

18 Cf. Hořejš, Protektorátní Praha (cf. n. 16), 86-90.

19 One whole issue of the journal was dedicated to the territory of former Czechoslovakia. Cf. Der Sudetenraum. Sudetengau, Böhmen und Mähren, sowie Teile Bayerns und Gaue Nieder- und Oberdonau. In: Raumforschung und Raumordnung 5/10-12 (1941), 502-524.

20 For photographs from Speer's visit in Prague in December 1942, cf. Čvančara, Jaroslav: Heydrich. Praha 2002, 61-63. 
The Nazi-controlled Land Department for Bohemia and Moravia (Bodenamt für Böhmen und Mähren, hereafter Bodenamt) had likewise originated in one of the departments of Protectorate Ministry of Agriculture. ${ }^{21}$ Its Group III (Gruppe III) included a construction department (Abteilung IVb - Bau d), headed by Gerhard Feldmann (1907-1944), who was an architect and SS-Standartenführer. The department included two sections, the names of which clearly indicate the Bodenamt's engagement not only in rural planning (and colonisation) but also urban development (and colonisation).

Traces of activity of the Bodenamt can be found in places such as Kladno (Kladen), Jihlava (Iglau), Kuřim (Gurein), and Poděbrady (Podiebrad). An interesting example of construction efforts can be found at the Bodenamt's farm in Vrbičany (Worwischan), a village north-east of Prague in the direction of Saxony, where a photograph shows a newly constructed granary.

Much like the RfR, which was shifting its focus away from agricultural areas and towards industrial agglomerations because of the strong prioritisation of industrial estates during the war, the Bodenamt also increasingly concentrated on urban settlements. This is why it was consulted on the visual aspect of projects such as the workers' colonies in Kladno and Kuřim, as described in detail below.

Close links between the Bodenamt and Germany are further evidenced by the engagement of Assistant Professor Werner Knapp (1903-1960), architect and graduate of the Technical University in Stuttgart, which made him member of the 'Stuttgart school' of architecture. Knapp consulted on many projects of village construction and redevelopment in the Protectorate with experts from his alma mater. During his stay in Prague, Knapp, active in publishing and editing, produced four volumes of the architecture journal Architektur-Wettbewerbe (published by the Karl Krämer imprint in Stuttgart). ${ }^{22}$

Existing departments of German universities in the Protectorate, especially of the German technical universities in Prague and Brno, were also involved in the process of transformation of Protectorate towns and rural areas. These universities received reinforcements in the form of politically reliable architects and urban planners from the Reich, who then participated in Nazi-organised architectonic tenders in the Protectorate. For instance, from the winter term of 1941 onwards, projects by the Department of Civil Engineering Planning projects included Professor Diez Brandi (1901-1985), who was recalled to Prague from Germany. He studied architecture in Stuttgart in 1922-1926 under Paul Bonatz (1877-1956) and Paul Schmitthenner (1884-1972), leading personalities of the Stuttgart school of architecture. ${ }^{23}$ The

21 On the significance of the agricultural sphere, cf. Štolleová, Barbora: Pod kuratelou Německé řiše. Zemědělství Protektorátu Čechy a Morava [Under the Custody of the German Reich. Agriculture in the Protectorate of Bohemia and Moravia]. Praha 2014, 42-96.

22 Cf. Hořejš, Protektorátní Praha (cf. n. 16), 129.

23 On Bonatz, cf. May, Roland; Voigt, Wolfgang; Sturm, Philipp: Paul Bonatz 1877-1956. TübingenBerlin 2010, and from a personal point of view Bonatz, Paul: Leben und Bauen. Stuttgart ${ }^{4} 1957$. 
German Technical University in Prague even counted on his services for the winter term of 1945 but, due to disagreements with local political representatives, Brandi had left the school much earlier, already in $1943 .{ }^{24}$

\section{Plans and Realisations in the City Areas}

Reichsprotektor Konstantin von Neurath headed the highest administrative authority in the Protectorate of Bohemia and Moravia, the which made him a key actor of Nazi power in the region. The supreme regional offices, Oberlandräte, which were created on 15 March 1939, functioned as subordinate elements in Protectorate administration. These offices were supposed to implement the policy of the Reichsprotektor and his office on a regional level. The authority of Oberlandräte was implemented in two ways: first of all, they supervised activities of Czech authorities within the relevant region, and secondly, they functioned as the administratively lowest official contact points for German citizens regarding affairs which were not within the jurisdiction of Czech or other German offices and authorities. ${ }^{25}$

Alongside other functions, therefore, Oberlandräte were supposed to take care of affairs of German citizens and to promote German interests within the relevant region. ${ }^{26}$ This placed them in a position where they could acquire a deeper understanding of local affairs and could not only implement but often even initiate various Germanising measures. ${ }^{27}$ Germans in the Protectorate had at their disposal a socalled Volkstumsfond, ${ }^{28}$ which was intended to finance various activities ranging from the construction of housing and German schools, to the support of German theatres, films, or students, all the way to subsidising things such as German healthcare and culture.

Oberlandräte also took steps against the mayors of a number of towns, whom they replaced by so-called government commissioners: Reich Germans who were loyal Nazis. In early July 1939, based on a decision by the Reichsprotektor, local authorities in Olomouc (Olmütz), Jihlava (Iglau), and České Budějovice (Budweis) were in effect replaced by these government commissioners who acted as mayors with extremely wide powers. By the end of 1940, all Protectorate cities with over 25,000

24 Cf. Hořejš, Protektorátní Praha (cf. n. 16), 177. On Brandi, cf. Freigang, Christian (Ed.): Diez Brandi (1901-1985). Ein Göttinger Architekt zwischen Tradition und Moderne. Göttingen 2002.

25 Cf. Verordnungsblatt des Reichsprotektors in Böhmen und Mähren (1939), 44.

26 According to German sources, out of the total Protectorate population of $7,380,000$, some 244,739 were German (3.31\%). In Moravia, the proportion was higher. There were 158,756 Germans $(6.23 \%)$ in a population of 2,549,300. In Bohemia, the corresponding proportion was just $1.78 \%$. Cf. Němec, Petr: Germanizační úsilí oberlandrátů na Moravě v letech 1939-1942 [Germanising Efforts of Oberlandräte in Moravia, 1939-1942]. In: Časopis Matice moravské 107 (1988), 183-195, here 184.

27 Ibid.

28 Fond für die Volkstumsarbeit im Protektorat Böhmen und Mähren. 
inhabitants had a German government commissioner. Assumption of power in key cities would then also enable their architectonic and urbanistic transformation to be carried out in the 'German spirit'.

Attempts to take control of the visual aspect of public spaces within Protectorate towns and cities proceeded over several stages and were interconnected with further Germanising steps. First came the removal of Czech national symbols and memorials, which commemorated key milestones, heroic achievements, and personalities from Czech history. This was followed by the renaming of streets, which was a characteristic indication of incoming Germanisation. These changes took place in hundreds of Czech and Moravian towns and cities regardless of the size of the local German community. This was also the first step in Nazis' efforts to systematically transform Czech and Moravian settlements, which were supposed to acquire a 'German character'.

Throughout the Protectorate, architectonic activities were limited by governmental directive no. 166, based on a decree by Karl H. Frank (1898-1946), State Secretary in the Reichsprotektor's Office and Higher SS and Police Leader for Bohemia and Moravia, which banned any new construction, effective as of 7 May $1941 .^{29}$ Building activities were to be stopped until Germany's 'final victory' (Endsieg). The ban, however, had a number of exceptions. It did not apply to public buildings of the Reich, to construction which Reichsprotektor's Office deemed beneficial to the state, its economy, or political aims, to construction costing up to 5,000 Reichsmarks, or to necessary maintenance works if permitted by the department of labour and social affairs of the pertinent of local Oberlandrat. Shortly afterwards, the Reich also issued a ban on planning, which officially halted the organisation of preparatory works and studies. Numerous projects had to be given up but surviving documents testify to the amount of the work done. If implemented, these plans would have led to a radical transformation of characteristic features of the territory of the Protectorate, a change in the appearance of a land that was for the most part not intended to be inhabited by Czechs.

As noted above, the influence of Nazi architects and urban planners in the Protectorate was quite significant and only the course of the war prevented a massive implementation of their projects. They focused, quite logically, on the two largest cities - Prague and Brno - as the most important centres of the country. They were the seats of numerous central German offices and institutions, both with a large German community and a long and continuous history. Other large industrial conurbations, such as Ostrava (Ostrau), Plzeň (Pilsen), Kuřim (Gurein), or Kladno (Kladen), were not spared significant interventions in their appearance either. Even smaller towns, especially those with larger concentrations of German administrative institutions and repressive units, as well as small cities with significant German communities (Streudeutschtum) were either affected by these changes or plans to do so were

29 Cf. Hořejš, Protektorátní Praha (cf. n. 16), 227. 
underway. All larger towns and administrative centres were eventually supposed to undergo transformation to highlight their allegedly 'German character'. ${ }^{30}$

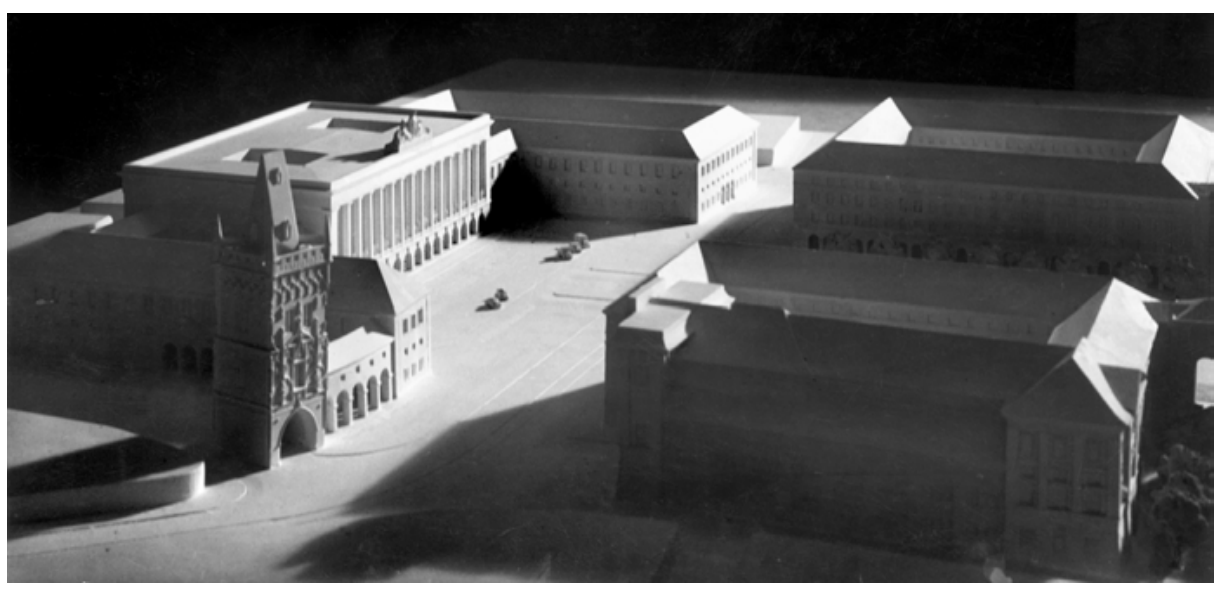

Fig. 1: Proposal of rebuilding of the centre of Prague (surroundings of The Powder Tower) by the architects Theiss and Jaksch from Vienna (Spisovna Útvaru rozvoje hlavního města Prahy).

For Prague, there existed several plans to thoroughly alter the character of the city centre. Fritz Lehmann (1889-1959) of the German Technical University in Prague produced a study which included the construction of buildings in the area of Hybernské Square. ${ }^{31}$ Paul Schmitthenner (1884-1972) presented a proposal for a new annex to the Old Town Hall, which included a re-urbanisation of the Old Town Square. ${ }^{32}$ Rudolf Hildebrand (1886-1947) and Erwin J. Ilz (1891-1954), both from Vienna, came up with a proposal for a 'North City' as a new part of Prague, while the Viennese architect firm of Theiss und Jaksch worked on an urbanistic transformation of the area around Prague's Main Railway Station. ${ }^{33}$ Richard Wagner of Leipzig proposed new access roads to the Little Town of Prague on the left bank of the Vltava River, while someone called Ing. Felddorf offered a study of an opera building in the Republic Square in Prague. The abovementioned Diez Brandi won a tender for the construction of a Hitler Youth hostel and a municipal hostel in Prague. The tender attracted 25 proposals, all by German architects. An exhibition introduc-

30 Cf. Hořejš, Miloš; Němec, Richard: National Socialist Urban Planning and Social Housing Development: Between Regulated Theory and Chaotic Reality. In: Rákosník, Jakub; Šustrová, Radka (Ed.): War Employment and Social Policies in the Protectorate Bohemia and Moravia, 1939-1945. Praha 2018, 69-90, here 89.

31 Cf. Hořejš, Protektorátní Praha (cf. n. 16), 135.

32 Cf. ibid., 189-192.

33 Cf. ibid., $276 \mathrm{f}$. 
ing the project was organised in Rưžová Street ${ }^{34}$ and was even covered by the press in Germany. ${ }^{35}$

Even one of the most prominent sites of Czech culture, the Rudolfinum, was renovated by the Nazis and officially 'returned to German culture' by Deputy Reichsprotektor Reinhard Heydrich (1904-1942) on 16 October 1941. This building, originally a concert hall and a gallery - and during the interwar period the seat of the Czechoslovak parliament - was taken over by the Nazi authorities shortly after creation of the Protectorate, with the intention of transforming it for the use of a newly created German concert orchestra. The rebuilding of the Rudolfinum was conducted under the auspices of the Office of the Reichsprotektor, within which Department IV (Abteilung IV) was responsible for cultural policy. The department was headed by Karl Freiherr von Gregory (1899-1944). It represented Goebbels's Reich Ministry of Public Enlightenment and Propaganda (Reichsministerium für Volksaufklärung und Propaganda $)^{36}$ and it seems that it was responsible for that part of conversion that had to do with choice of a musical body and other affairs that had to do with its intended function. The practical execution of rebuilding of Rudolfinum fell, within the Reich Protector's Office, to Group Z, which was headed by Construction Councillor (Baurat) Friedrich Mittmayer (b. 1906). ${ }^{37}$ The reconstruction was to be paid for by the Protectorate Ministry of Public works. A Czech architect, Antonín Engel (1879-1958), ${ }^{38}$ whose neo-Classicist style was inoffensive enough for the Nazis to tolerate, was then put in charge of design of the reconstruction. In the end, despite various complications and delays, the reconstruction of Rudolfinum was completed.

In Brno, the largest Moravian urban centre, architecture was an instrument of competition between the Czech and German speaking communities ever since the second half of the nineteenth century. Each significant achievement of the one side

34 Basic information for the exhibition came from the personal archive of Eugen Blanck, member of the Planning Commission for the Capital City of Prague and Its Surrounding, kept in Cologne Historical Archives. Sadly, these materials are currently inaccessible due to damage; cf. Historisches Archiv der Stadt Köln. Coll. 1279 Blanck, Eugen. Box A 26. 1940-1941: Ausstellung des Wettbewerbs für ein H. J. Heim auf der Schützeninsel, 1940.

35 E. g. in the special volume of Die Kunst im Deutschen Reich 4 (1940). Ausgabe B: Die Baukunst, 16.

36 Cf. Fauth, Tim: Deutsche Kulturpolitik im Protektorat Böhmen und Mähren 1939 bis 1941. Göttingen 2004, 25; Gerwarth, Robert: Reinhard Heydrich. Hitlerův kat [Reinhard Heydrich. Hitler's Executioner]. Praha 2012, 277.

37 Graduate of the Technical University in Darmstadt (Dipl. Ing. 1931 in structural engineering). In September 1943, he was drafted to the Wehrmacht. Cf. NA Praha. Coll. Úřad řǐšského protektora (ÚŘP) [Amt des Reichsprotektors]. Unprocessed material.

38 Cf. NA Praha. Coll. ÚŘP. Box 535. No IV-2 F. Rudolfinum (stavební opravy, znovuotevření) 19391943 [Rudolfinum (construction repairs, reopening) 1939-1943]: File Rudolfinum. Allgemeines und Hausverwaltung. 20.08.1940; Novotný, Michal: Poslanecká sněmovna v Rudolfinu. Rudolfinum $\mathrm{v}$ moci nacistů [Chamber of deputies in the Rudolfinum. Rudolfinum in the Power of Nazis]. In: Bachtík, Jakub; Duchek, Lukáš; Jareš, Jakub (Ed.): Chrám umění Rudolfinum / The House of Artists Rudolfinum. Praha 2020, 281-364. I would like to thank Michal Novotný for sharing his manuscript. 
tended to inspire a building constructed in the relevant national style on the other side. During the interwar era, Brno became a fast-developing urban centre where modern architecture, especially the so-called 'white functionalism', was extremely well represented. ${ }^{39}$ In fact, the number of avant-garde buildings constructed here was truly unparalleled in contemporary Europe. Most were designed by Czech and Jewish architects and the whole enterprise was part of efforts to weaken the 'German' spirit of pre-war Brno. During the Second World War and German occupation, this led to a highly visible German reaction.

In 1941-42, the Špilberk (Spielberg) Castle in Brno was subjected to neo-historicising alterations by the construction department of the Wehrmacht. They were executed by Herbert Neubert (1909-1996), an architect chosen by the Wehrmacht, which used the compound as a dormitory. These alterations are a classic example of the use of traditional and monumental forms of Nazi architecture. ${ }^{40}$

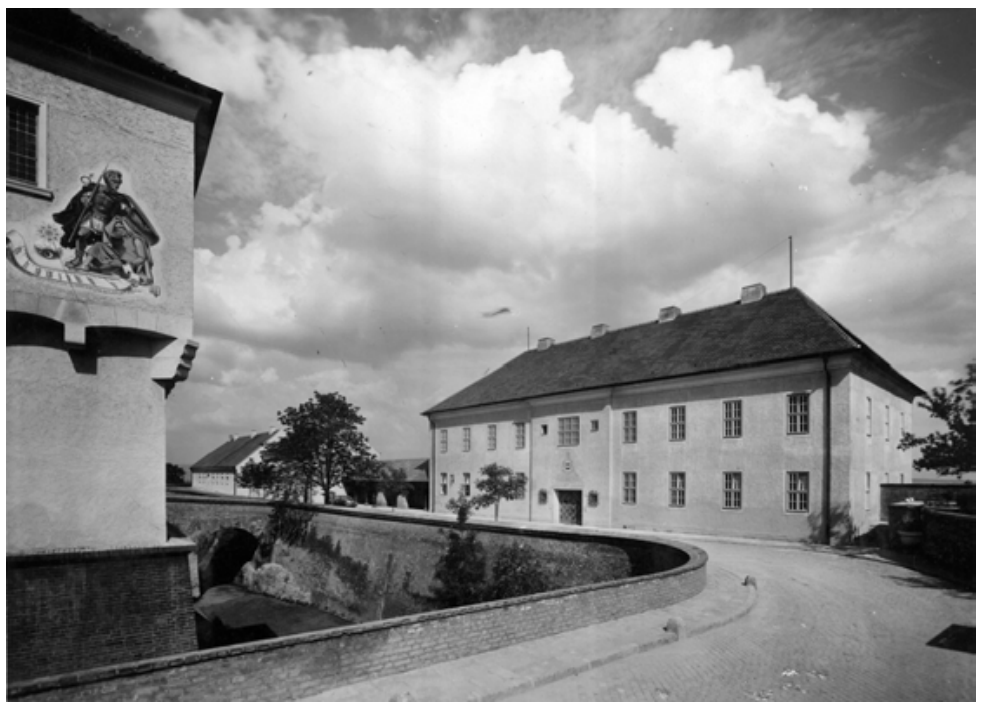

Fig. 2: Špilberk Castle in Brno was subjected to neo-historicising alterations by the construction authorities of the German armed forces (Muzeum města Brna, fotoarchiv).

39 Adolf Loos, one of the leading representatives of Central European Functionalism, said regarding the German House in Brno, which since its opening in 1888 served as the centre of German life in the town, the following in 1924: "Any time I was in Brno and looked at the German House and the Czech Club, the character of the two buildings immediately told me what would eventually happen to [German] Brno. It is so evident!” Loos, Adolf: O šetrnosti [On Thrift]. In: Bytová kultura 1/2-3 (1924/25), 17-21, here 20; also in idem: Řeči do prázdna [Speech into Emptiness]. Praha 1929, 151-164, here 161. Cf. Chatrný, Jindřich; Černoušková, Dagmar; Koř́nková, Jana [Ed.]: Evropan Adolf Loos. Nejen brněnské stopy / Adolf Loos. European. His Legacy in Brno and Beyond. Brno 2020, 49. 40 Cf. the official German press release containing several contemporary photographs: Der Spielberg einst und jetzt. In: Unsere Wehrmacht im Protektorat Böhmen und Mähren 3/19 (1941), 4-6. 


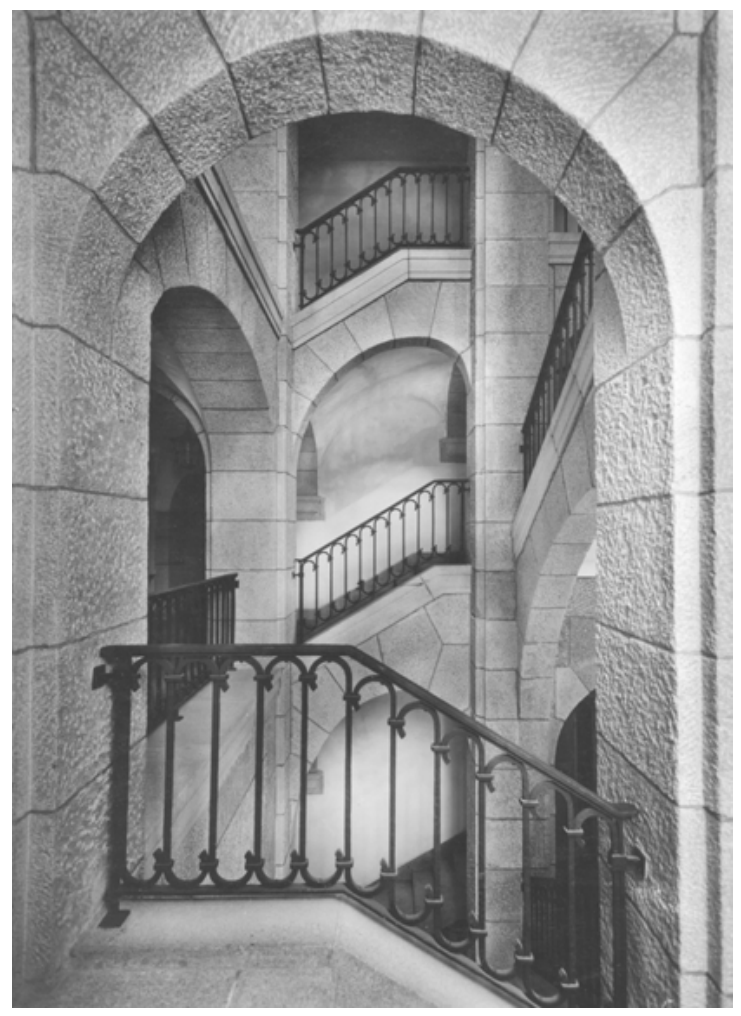

Fig. 3: Staircase of Špilberk Castle (Muzeum města Brna, fotoarchiv).

The reconstruction of the Špilberk Castle in Brno demonstrates another important feature of German intervention in the urban planning of Protectorate towns and cities, namely their approach to cultural heritage. Because Špilberk is a historical complex, Herbert Neubert, the architect, invited Karl Friedrich Kühn (1884-1945). Kühn was a native of the Bohemian town of Trutnov (Trautenau), Professor of Heritage Protection and 'Protection of Homeland' (Heimatschutz), who headed the Institute for the History of Construction and History of Art at the German Technical University in Prague. ${ }^{41} \mathrm{He}$ went to the Viennese Military Archives to study materials pertinent to the Špilberk fortress ${ }^{42}$ and conducted a historical building survey, which was published later. Although, from a technical viewpoint, he produced a

41 Cf. Zeman, Jaroslav: Pozapomenutý historik umění Karl Friedrich Kühn (1884-1945) [The HalfForgotten Art Historian Karl Friedrich Kühn (1884-1945)], In: Sborník Národního památkového ústavu, Územního odborného pracoviště v Liberci [Anthology of the Office for Heritage Conservation, Regional Specialised Office in Liberec]. Liberec 2007, 85-89.

42 Cf. Kudělková, Brněnská architektura (cf. n. 4), 59. 
highly erudite study, there was a definite emphasis on the German influences which determined the form of the original medieval castle. ${ }^{43}$

After Stanislav Sochor, the Czech head of the Office for Heritage Conservation (Úřad památkové péče) ${ }^{44}$ in Brno was pensioned off, Kühn was appointed to his position in 1941. After a subsequent merger of the Office for Heritage Conservation in Brno with the Office for Heritage Conservation for Moravia and Silesia, also in 1941, Kühn was, as head of the Brno office, appointed to the post of deputy to Wilhelm Turnwald (1909-1984) who was head of the now joint cultural heritage protection office. ${ }^{45}$ After Turnwald joined the army in early 1942, Kühn was put in charge of the entire amalgamated office during his absence, and until the end of the war. This placed Kühn in a position of direct influence on cultural heritage care in the entire Protectorate. He played a significant role in deciding the fate of numerous heritage sites: buildings, but even, for example, bronze memorials, which were supposed to be melted and given to the disposal of the war industry. ${ }^{46}$ Kühn was also responsible for cultural heritage protection towards the end of the war, at a time of increased threat of damage and destruction during air raids. ${ }^{47}$

The Nazi regime also exhibited its 'new order' in occupied towns through engineering projects, such as the construction of new roads. In Brno, for instance, the Nazi authorities managed to complete a long-planned road leading from the main

43 Cf. Kühn, Karl F.: Der Spielberg in Brünn - eine deutsche markgräfliche Pfalz - Ein Beitrag zur Geschichte der Kunst des Mittelalters im deutschen Osten. Brünn 1943 (Schriften der Deutschen Gesellschaft der Wissenschaften).

44 This office was later renamed in Regional Heritage Office (Zemský památkový úřad), cf. Uhlíková, Kristina: Karl Friedrich Kühn. In: Biografický slovník památkové péče [Biographic Dictionary of Heritage Care], online. 23.10.2013. URL: http://npu-cz.temp141.imagic.cz/biograficky-slovnik-pa matkaru-I/kuehn-karl-friedrich/ (22.01.2021).

45 Cf. Uhlíková, Kristina: Wilhelm Karl Turnwald. In: Ibid. 25.10.2013. URL: http://npu-cz.temp141. imagic.cz/biograficky-slovnik-pamatkaru-I/turnwald-wilhelm-karl/ (22.01.2021); cf. also Turnwald, Wilhelm (Ed.): Dokumente zur Austreibung der Sudetendeutschen. München 1951.

46 Cf. NA Prague. Coll. ÚŘP (stock II.). Box 536. No I-10.

47 Based on evidence we have today, Kühn's activities within Protectorate heritage protection can be viewed in a highly positive light. He is especially respected by experts for his 1938 study called Fliegerschutz für Kunst- und Kulturdenkmäler, where he presented innovative approaches to heritage conservation during wartime. Cf. Kadlecová, Žaneta: Ochrana sakrálních památek na území hlavního města Prahy v období Protektorátu Čechy a Morava [Protection of Sacral Heritage on the Territory of the Capital City of Prague During Protectorate Bohemia and Moravia]. In: Nová, Magdaléna; Opatrná, Marie (Ed.): Vidět, slyšet, číst, rozumět. Sborník příspěvků mezinárodní konference studentů doktorských studijních programů [See, Hear, Read, Understand. Collected Contributions from International Conference of Students of Doctoral Programmes]. Praha 2015, 217-222; Kadlecová-Vobořilová, Žaneta: Protiletecká opatření architektonických památek na území Prahy v letech 19391945 [Anti-Aircraft Measures to Protect Architectonic Heritage on the Capital City of Prague, 19391945]. In: Nová, Magdaléna (Ed.): Staré a nové. Staré jako východisko, či překážka? Sborník př́spěvků mezinárodní konference studentů doktorských studijních programů [Old and New. The Old as a Starting Point or an Obstacle? Collected Contributions from International Conference of Students of Doctoral Programmes]. Praha 2016, 331-336. 
train station through Koliště and Joštova Street to the present Komenského Square. ${ }^{48}$ Construction of this road with tram rails took almost two years, 1940 and 1941. This intervention into Brno's transport system eased the heavy traffic in the centre. The road was opened on 6 May 1942 with a ceremony attended by Oskar Judex (1894-1953), the government commissioner (effectively the mayor) of the city of Brno, and many other Nazi representatives. ${ }^{49}$ The project of linking Hus Street with Nádražní Street, as well as creation of what is now M. Horákové Street, is usually ascribed to Czech civil engineer Jaroslav Grunt (1893-1988), but his name does not figure in any of the articles cited here. In fact none of them cites any city planner. Regarding the abovementioned road, Oskar Judex wrote to Karl H. Frank:

"Creation of this street is of extremely high importance for solving the difficult traffic situation in Brno. In the future, it should ease up the traffic in the inner city and boost the possibilities of transportation of goods. Plans to build this street had been prepared already in 1908 and until 1918, the project sought support for its realisation. In 1918-1935, the Czech municipal representatives tried to implement it, but in the end the project was realised by National Socialist municipal leadership." 50

Results of 'successful' construction projects in the Moravian metropolis in late 1930s and early 1940s were summarised and presented at the 'Three Years of Building' (Drei Jahre Aufbau) exhibition, organised by the Nazi administration. The exhibition took place between the $15^{\text {th }}$ and $31^{\text {st }}$ of March 1942, in the New Town Hall (Nova radnice) on the occasion of the third anniversary of the Protectorate. ${ }^{51}$ The Nazis presented an apartment building/department store, found in what is now Masarykova

48 The road went through a cut in the stony slopes of the Denis Park, which effectively connected an existing smaller circular road with Šilingr Square.

49 In 1942, Judex said the following about the interwar architecture of Brno, which turned the town into a veritable textbook of Functionalism: "Planning and construction projects were pushed through which in many ways cannot have been advantageous for the town. Results of this activity formed the current skyline of the town and it will take dozens of years before the results of this work created by a petty group using extra-terrestrial [sic] architecture that is completely unsuited to our conditions will disappear [...]. It was thus necessary to start new planning from the perspective of national socialist urbanism [...]. In part, we managed to imbue the town, Brno, with a friendlier image and to bring it back to the people who live here.” Judex, Oskar: Neue Aufgaben und Ziele. In: Der Bau. Fachzeitschrift des Verbandes der Baumeistergenossenschaften für Böhmen und Mähren mit dem Sitze in Prag 1 (1942), 62.

50 NA Praha. Coll. AMV-110. Box 23. No 110-4/171. For more on Judex's plans to rebuild the German Municipal library in Brno (the so-called 'Schmetterhaus'), funded by the Volkstumsfond, cf. NA Praha. Coll. ÚŘP. Box 535. No I-10 V-4-1 1939-1944. See also Slavnostní otevření prodloužené Husovy ulice [Festive Opening of Extended Husova Street]. In: Internetová encyklopedie dějin Brna [Internet Encyclopaedia of the History of Brno]. 10.12.2019. URL: https://encyklopedie.brna.cz/ home-mmb/?acc=profil_udalosti\&load=302 (22.01.2021).

51 Kudělková, Brněnská architektura (cf. n. 4), 62. Emil Leo’s plans to build a new cultural centre, city gallery, museum, and a library remained on paper. Cf. Kroupa, Jiří; Pelčák, Petr; Wahla, Ivan (Ed.): Brněnští němečtí architekti / Brno German architects: 1910-1945. Brno 2012, 97. 
Street, as an example of a building that would meet the criteria of the new direction in construction. It was built in 1939-1940 based on a design by German architect Dipl. Ing. Walter Orliczek (b. 1900). ${ }^{52}$ The front of the building conformed to the Nazi-promoted historicising style..$^{53}$

A new housing estate was also built for the German community in Brno's Komárov (Kumrowitz) quarter. This was supposed to prevent Germans leaving the Moravian metropolis through a lack of suitable housing. According to Oskar Judex, this new development had abandoned the "earlier system of building 'small apartments' and these were built in accordance with directives valid in the Reich". ${ }^{54}$ This presentation of achievements of the town hall under German leadership clearly served the purposes of propaganda: it functioned as a self-promotion of the Nazi regime.

Professor Emil Leo (1894-1974), a graduate of the German Technical University in Brno, was also active there. These ranged from urban regulation, city planning, and consultations all the way to the reconstruction of historic buildings. Between 1938 and 1945, he worked as an urban planner in Jihlava, Místek (Mistek, during the Protectorate: Freiberg), Přerov (Prerau), Olomouc, and Brno. During the war, in addition to projects intended for Jihlava, he also submitted a proposal for 'Poldi Siedlung', a colony and cultural centre in Kladno, and, in November 1940, a project for Hitlerjugend headquarters at Střelecký Island (Schützeninsel) in Prague. In a design competition for the former, his proposal was third among five submissions, while in a competition for the latter, his project was not even among the first ten of the twenty-five projects submitted..$^{55}$ During the occupation, Leo held the post of advisor for construction to the mayor of Brno with direct powers to take decisions. In this case, however, he was not involved in the construction of new buildings but in the restoration of cultural heritage.

In Olomouc, another large Moravian city, he submitted various plans for the restoration of historic buildings in 1942-1943, as well as a proposal for an economic plan that sought to not only respect to the past, especially the different manifestations of the genius loci in various places - ranging from the historic centre all the way to the peripheries of the city - but also many new ideas. In this case, criticism

52 The original building jutted into the street and was an obstacle for street transport.

53 Kroupa/Pelčák/Wahla (Ed.), Brněnští němečtí architekti (cf. n. 51), 29; Judex, Neue Aufgaben und Ziele (cf. n. 49), 69.

54 Judex, Neue Aufgaben und Ziele (cf. n. 49), 68.

55 For further details, cf. Hořejš, Miloš: Aplikace nacionálněsocialistické architektury v českých zemích v 1. 1938-1945 [Implementation of the National Socialist Architecture in the Czech Lands, 1938-1945]. In: Dějiny vědy a techniky 15 (2007) (Rozpravy Národního technického muzea 203), 4571, here 65; idem: Kladenská kolonie "Siedlung" jako př́lklad politické instrumentalizace architektury' [Kladno 'Siedlung' Colony as an Example of Political Instrumentalization of Architecture]. In: Schmelzová, Radoslava; Šubrtová, Dagmar (Ed.): Kladno minulé a budoucí [Kladno Past and Future]. Kladno 2007, 65-76; idem, Protektorátní Praha (cf. n. 16), 287. 
of the previous interwar regime was supposed to lead to the first systematic modern attempt at a reconstruction of old Olomouc: "Regardless of financial sacrifices, the German spirit and strength was supposed to save the decrepit body of the town and lift it to the level of Gothic and Baroque Olomouc."56 The proposal embodied a desire to 'rebuild the old condition' wherever it had been disturbed or destroyed. ${ }^{57}$

One project that was viewed as a model worth following in the active protection of Olomouc's old town was the reconstruction of the front façade of house known as Špalíček in the Upper Square (Horní náměstí), by the Czech architect Klaudius Madlmayr (1881-1963). In the end, however, the proposals of Karl Fischer (1901-1948), Olomouc town hall's advisor for architecture, had the most decisive impact. Aside from changes to the façade of several palaces, he designed and implemented an extensive reconstruction of the exterior as well as interiors of the Municipal Theatre (1940-41), which was given back to a German theatre company after the interwar period. ${ }^{58}$ Unrealised plans to 'rebuild the old condition' of buildings were put forward by several other Olomouc architects: such as Heinrich J. Czeschner (18691945), Hans Stratil (1900-1981), and Josef Macharáček (1880-1943). ${ }^{59}$

Examples of efforts to transform the seat of the local German Oberlandrat can, for instance, be found in the Moravian town of Jihlava as well as in Kolin, in Central Bohemia. In Jihlava, Heimatstil was combined with neo-historicism in the newly built Hitler Youth Hostel (Hitlerjugendheim) in 1940-41, designed by Helmut Weber who was a German architect from the Reich Association for German Youth Hostels. Ideological supervision of the architectonic form was provided by another German architect, Friedrich (Fritz) G. Winter (1910-1986), who was appointed to supervise constructions of Hitler Youth Hostels in Bohemia. The relatively well-known construction on a hill in the Březina Park dominates other no less interesting urban and architectural developments in Jihlava, which were completed around the same time. At about this time, the abovementioned Emil Leo also came up with a new regulatory plan for the town. Aside from this, he also proposed a rebuilding of the municipal theatre in 1939 and, in early 1940s, submitted plans for reconstruction of the former Czap Hotel, known later as Jihlava Inn (Jihlavský dvưr), and the German House (Deutsches Haus): nowadays known as the Workers' House (Dělnický dům). ${ }^{60}$

56 Zatloukal, Pavel: Olomouc. Praha 2013, 38; idem: Meditace o městě, krajině, umění: Olomouc 1919-1989 [Meditation on the City, Landscape, Art: Olomouc 1919-1989]. Olomouc 2021.

57 Cf. Fischer, Karl: Aufstieg der Baukultur in Olmütz. In: Der Bau 1/38 (1942), 128-130.

58 He not only removed additional ornaments from the front of the building but even some of the original Empire style details. The foyer, including staircases, was completely new, and even the auditorium was subjected to some alterations. Cf. ibid., 129.

59 Ibid.

60 Cf. Leo, Emil: Die Stadt Iglau im Aufbau. In: Der Bau 1 (1942), 85-90; Šišma, Pavel: Učitelé na německé technice v Brně 1849-1945 [Teachers at the German Technical University in Brno, 18491945]. Praha 2004 (Práce $z$ dějiny techniky a přírodních věd 2), 115; Leo, Emil: Zum 70. Geburtstag des Architekten, o. ö. Prof. Dr. techn. Ferdinand Hrach. In: Mitteilungen des Hauptvereines deutscher Ingenieure in der Tschechoslowakischen Republik 21/11 (1932), 1 f. See also 'Emil Leo'. In: 
The urban landscape of Jihlava during the Protectorate was marked by several locations where apartment construction was taking place, based on plans by the German architect Otto Schloss. ${ }^{61}$

Like in Jihlava and Brno, České Budějovice was another town where the German-speaking community played an important role until the creation of Czechoslovakia. Here, after the creation of the Protectorate, Nazi authorities tried to leave their mark on the urban and architectural features of the town in order to bring it visually closer to the style of German agglomerations. In the early 1940s, they came up with a relatively detailed model of the town that reflected their fantastic vision. Almost the entire town, from east to west, was to be intersected by a new, impressive urbanistic axis; somewhat akin to the north-south axis in Berlin. This avenue was to be dominated by a large tower in the form of a lighthouse from classical antiquity. The project also featured a large stadium in the style of an ancient amphitheatre. The realisation of this grandiose project would have run into immense technical problems, yet it is quite evident that the idea was meant seriously. ${ }^{62}$

Just like in Jihlava, there were plans to build social housing that would demonstrate Nazi regime's care of the German community. For instance, in 1940-41, the idea of building of a housing estate was promoted by Friedrich David (1900-1945), government commissioner of the town; at the instigation of the Oberlandrat's office and local leadership of the NSDAP. David tried to involve a public benefit society from Linz (Wohnungs- und Siedlungsgesellschaft der Deutschen Arbeitsfront im Gau Oberdonau 'Neue Heimat' in Linz) in the project, known as the 'New Home'. This colony was supposed to be located at Dlouhá louka, somewhere between Na Sádkách and Litvinovická streets. In the end, though, the scheme collided with the route of a new planned road that would lead to the military airport in Planá (Plan), which had a higher priority. Another factor was a restriction on construction activities in the Protectorate adopted later in the war. ${ }^{63}$

Even so, České Budějovice did receive its share of buildings in the monumental style, promoted by the National Socialist regime. In the autumn of 1940, the Nazis took over the building of the South Bohemian Theatre and handed it to the German City Theatre Budweis (Deutsches Stadttheater Budweis), the local branch of a theatre

SüdmährenWiki (05.02.2009). URL: http://portal.suedmaehren.at/wiki/index.php/Emil_Leo (23.01.2021).

61 Cf. Hořejš, Miloš; Němec, Richard: Urbanismus a architektura Jihlavy ve službách komunální politiky nacionálního socialismu [Urbanism and Architecture of Jihlava in the Service of the Communal Policy of National Socialism]. In: Jedlička, Jiří (Ed.): Češi a Němci na Vysočině. Soužití, rozdělení, dialog, spolupráce / Tschechen und Deutsche in der Vysočina. Zusammenleben, Trennung, Dialog, Zusammenarbeit. Havlíčkův Brod 2014, 357-392.

62 Cf. Kovář, Daniel; Binder, Milan: Projekty ze šuplíku. Nerealizované nápady, které mohly změnit České Budějovice [Projects from the Drawer. Unrealised Ideas that Could Have Changed České Budějovice]. České Budějovice 2018, 21.

63 Cf. ibid., 22. 
in Linz, Upper Austria. The construction of an associated technical building comprising workshops and storage spaces, as well as actors' houses - which were supposed to accommodate both actors and employees of the institution - began in 1941/42. The building featured a coffee bar, restaurant, and several shops on its ground floor. The project was a work of the Viennese architect and theatre designer Ceno Kosak (1904-1985). ${ }^{64}$

In Kolín (Kolin), Central Bohemia, Oberlandrat Herbert E. Eckholdt (b. 1906) initiated the rebuilding of former military administration building of the Czechoslovak Army, which had been turned into Gestapo headquarters and the seat of the Oberlandrat. The adaptation was carried out in the spirit of the monumental neoclassicism. In 1941, a new Hitler Youth Hostel was constructed in Heimatstil based on plans by Siegfried Wähner (b. 1914), a junior lecturer at the German Technical University in Prague. The dominant aspect of this building was a lofty roof, a feature which was reinforced by its location high above one of Prague's arterial roads. Kolín had also received an 'emergency colony' (i. e. impromptu housing) for four families. This colony, in Heimatstil, was designed on the initiative of Herbert E. Eckholdt by the Czech architect Jaroslav Fragner (1898-1967). ${ }^{65}$ It housed German officials, state officials, teachers, and industrial employees with their families. Although the colony was supposed to house Germans, Kolin - although officially bankrupt and having been run by an administrative commission rather than an elected city council since the late 1930s - had to pay for its construction. To finance this undertaking, the town had to take out a loan. ${ }^{66}$

In Prostějov (Proßnitz), too, Oberlandrat Dr. Josef Bayerl (b. 1894) showed considerable initiative in considering a visual transformation of this regional centre. In this town, where prior to the occupation, German community with 780 persons formed just about $2.3 \%$ of population, municipal affairs were now governed by a newly appointed administrative commission headed by JUDr. Hermann Böss, a German who was previously employed by the Oberlandrat. By May 1940, however,

64 Cf. Dvořák, Jiří et al.: České Budějovice pod hákovým křǐ̌em [Budweis Under the Swastika]. České Budějovice 2015, 127-128; Erbanová, Eva; Šilhan, Milan; Švácha, Rostislav (Ed.): Slavné vily Jihočeského kraje [Famous Villas of Southern Bohemia]. Praha 2007.

65 Cf. Novotný, Michal: Jaroslav Fragner and the Unrealised Project of Industrial Town in KolínZálabí. In: Ševeček, Ondřej; Jemelka, Martin (Ed.): Company Towns of Bata Concern. History - Cases - Architecture. Stuttgart 2013, 201-217; idem: Jaroslav Fragner a urbanismus města Kolína [Jaroslav Fragner and Urbanism of Kolín Town]. In: Královéhradecko 7 (2010), 237-263.

66 Cf. Hořejš, Miloš; Němec, Richard: National Socialist Urban Planning and Social Housing Development: Between Regulated Theory and Chaotic Reality. In: Rákosník, Jakub; Šustrová, Radka (Ed.): War Employment and Social Policies in the Protectorate Bohemia and Moravia, 1939-1945. Praha 2018, 69-90, here 86. For more on architect Emil Leo, cf. Hořejš/Němec, Urbanismus a architektura Jihlavy (cf. n. 61), 358-360. 
Böss - who turned out to be rather moderate - was replaced by Maxmilian Girth, a fervent Nazi who managed to push through a thorough redesign of the local National House. ${ }^{67}$

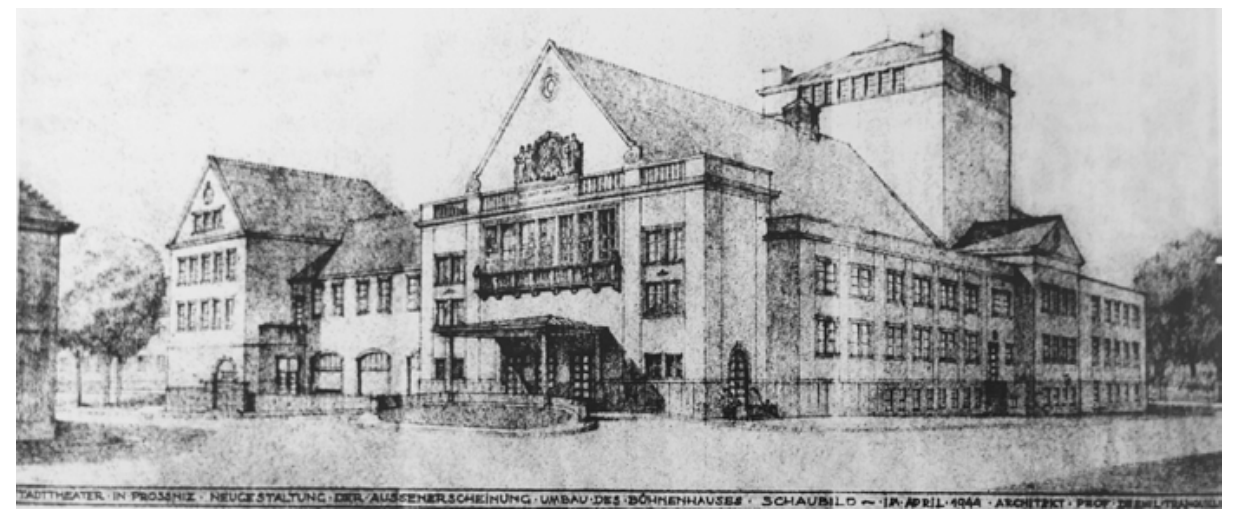

Fig. 4: Proposal of redesign of the local National House in Prostějov designed by the German architect Emil Tranquillini (Source: Národní dům v Prostějově 1907-2007. Prostějov 2007, 182).

This building, which served as the hub for the Czech nationals in the town, was constructed in 1906-1907 in the style of Art Nouveau based on a design by Jan Kotěra (1871-1923). Now it was to be altered so as to suit current German taste and serve as the seat of a German theatre company. The rebuild was undertaken in a style corresponding to Nazi ideology and its architecture of sternly classicising expression. The project was designed by Emil Tranquillini (1884-1955), an architect from Brno who taught at the German Technical University there. In September 1941, he submitted a complete project which considered both the much-needed addition of backstage facilities and a thorough redesign of the outer appearance of other parts of the compound. The proposal included a removal of all Art Nouveau elements and artwork (murals, statues, etc.) to wipe out the Czech character of the building. The rebuild, which started in 1942, affected all public spaces of the theatre, especially the entrance hall, which survives in the Nazi-rebuilt form to this day, but also the staircases, corridors, backstage salons, and the auditorium. ${ }^{68}$

67 Girth stayed in this function until 1942 and, in 1944, was also appointed mayor. Cf. Vojtek, Libor: Vývoj obecní samosprávy v Prostějově od poloviny 19. do konce 20. Století [The Development of Municipal Self-Governance in Prostějov from mid-19. until the End of the 20. Century]. Unpublished thesis. Faculty of Law. Masaryk University. Brno 2015, 34; State Regional Archives Prostějov. Fonds Archiv města Prostějova. Inv. no. 2076. Reg. no. 3629. Book 354: Rozpuštění městského zastupitelstva a jmenování vládního komisaře [Dissolution of municipal representation and appointment of a government commissioner], items 2, 4, 7 and 13 (1940).

68 These interventions fortunately only affected the external appearance minimally. Cf. Marek, Pavel: Stavební proměny Národního domu 1907-2007 [Building Alterations of the National House, 
An architectonic tender for an administrative centre of a new colony in Kladno, the Poldi-Siedlung, was by invitation only and just five preselected German architects were asked to participate. Four of them were professors from technical universities: Wilhelm Jost (1874-1944) from Dresden, Emil Leo from the German Technical University in Brno, Friedrich Zotter (1894-1961) from Graz, and Professor Diez Brandi from the German Technical University in Prague. The sole person who did not come from a technical university was W. Platzer from Linz. The tender went to Emil Leo, architect already mentioned above in connection with the rebuilding of Jihlava.

Another important industrial hub was Moravská Ostrava (Mährisch Ostrau) in Moravia. It, too, became the subject of plans for a far-reaching architectonic and urbanistic transformation. This metropolis of northern Moravia was the seat of Oberlandrat Dr. Karl von Rumohr (1900-1967) and his office was responsible for municipal authorities of Moravská Ostrava, Frýdek, and Místek. Ostrava, too, received its German government commissioner: Josef Hinner (1899-1951) was appointed to this office in July 1939. In 1940, he was replaced by SS-Sturmbannführer Emil Beier (1893-1985), who was until then mayor of Opava (Troppau). ${ }^{69}$

Importantly, Beier arranged that Moravská Ostrava was promoted to a statutory town. In 1941, twelve Silesian and Moravian settlements were incorporated into Moravská Ostrava, which led to the creation of so-called 'Greater Ostrava'. This unification of Ostrava's municipalities into one town was not only inspired by efforts at better planning for Ostrava's further development; it was also a step that enabled Beier to dissolve the Czech councils of the now integrated municipalities and assume control over them. In this case, urbanistic planning clearly went hand in hand with Germanising efforts. One year later, on 7 July 1942, Beier was appointed mayor of the entire Moravská Ostrava region by Dr. Karl Schwabe (1899-1946), regional vice-president. ${ }^{70}$ Under Beier's leadership, over 2,000 housing units were built in Ostrava.

This construction effort reflected an increase in the number of workers in local industry, which to a large extent produced goods for the German war effort. The mining and steel works in Karviná-Třinec (Berg- und Hüttenwerkgesellschaft KarwinTrzynetz) during the German occupation built for its workers' families a housing es-

1907-2007]. In: Roháčková, Dagmar (Ed.): Národní dům v Prostějově 1907-2007 [The National House in Postějov, 1907-2007]. Prostějov 2007, 163-198.

69 At the beginning of the occupation, Moravská Ostrava had a population of app. 130,000, of whom about 25,000 claimed German nationality. See Historický lexikon obcí České republiky 1869-2005 [Historical Lexicon of Municipalities of the Czech Republic]. Vol. 1. Praha 2006, 51-54. 70 Cf. Nenička, Lubomír: Městská správa v době nacistické okupace. Př́činy a důsledky vzniku Velké Ostravy v roce 1941 [Municipal Administration During Nazi Occupation. The Causes and Impact of Creation of Greater Ostrava in 1941]. In: Theatrum historiae 16 (2015), 241-244; Przybylová, Blažena; Šerka, Josef: Muži s mocí: Portréty představitelů města Ostravy 1918-1989 [Men of Power: Portraits of Representatives of Ostrava City]. Šenov u Ostravy 1999, 32-34. 
tate in Ostrava-Mariánské hory (Marienberg). Unlike the original houses in that locality, these blocks were organised in an open fashion. In practice, two types of apartment layout were built and allocated depending on the size of the family. ${ }^{71}$ It was planned that, in future, green areas would be established between the existing old houses. It was also planned that existing blocks of houses would be added to so as to form closed, U-shaped blocks, open to the south-east to let in the light and the sun. ${ }^{72}$

Due to a boom in production, Vítkovice Steelworks (Witkowitzer Eisenwerke), part of Reichswerke Hermann Göring, paid special attention to social housing. The management had ordered a "creation of worker's colonies in accordance with current conditions and demands of healthy housing”, but due to shortage of suitable large areas for building and because of difficulties in linking the remaining locations to transport infrastructure, in the end it was necessary to abandon "plans to build a large housing development, a self-contained suburb, where airy squares would be linked to broad streets, spacious gardens, surrounding nature, and agricultural landscape."73 A suitable location was found in Ostrava-Hrabůvka (Klein Grabau), where some 830 apartments would be built in 135 houses in an area of 14 hectares. ${ }^{74}$ This new construction followed up on the existing Jubilee Colony built by Vítkovice Steelworks in 1921-1932. ${ }^{75}$ Under Beier’s leadership, a new bridge linking Ostrava-Vítkovice and Kunčice (Klein Kuntschitz) was opened on 10 October 1942 and improvements were also achieved in the sewage system, road system, and public transport. ${ }^{76}$ The abovementioned Emil Leo also designed a housing estate

71 The core was a dining room with a large living room or a joined dining and living room. Each apartment also had all auxiliary facilities, such as an entrance hall, a pantry, toilet, cellar, and an attic room. Cf. Marzelli, Erwin: Der soziale Wohnhausbau der Bergindustrie Mährisch Ostraus im Kriege, in: Der Bau 2 (1943), 11.

72 The resulting large court was to be turned into playgrounds with lawns and paddling pools. All temporary buildings and stables were to be removed from the colony's surroundings so as to remove the rural character of the estate. Cf. ibid.

73 This is how master builder Alois Pix from the construction department of Vitkovice Steelworks described the situation. Cf. Pix, Alois: Der soziale Wohnungsbau im Eisenwerk Witkowitz, in: Der Bau 2 (1943), 13.

74 The construction of a network of sewage pipes, water ducts, electricity, roads, and gardens with trees for 44 houses with 250 apartments was all completed during the war. The apartments had two to four rooms and each included a kitchen, dining room, entrance hall, and a bathroom with a toilet. The construction of another colony, which was supposed to also include a shop, school, cultural centre, meeting house, a kindergarten and other facilities remained only on paper. Cf. ibid. 75 Cf. Přendík, Petr; Sed’a, Radomír; Strakoš, Martin: Jubilejní kolonie: 90 let dělnické kolonie v Ostravě-Hrabůvce [Jubilee Colony. 90 Years of Workers’ Colony in Ostrava-Hrabůvka]. Ostrava 2018; Jemelka, Martin; The Fight for Roof over One’s Head: Housing Policy in Ostrava Coal Mining Companies and the Vítkovice Mining and Iron Corporation (1939-1945). In: Rákosník, Jakub; Šustrová, Radka (Ed.): War Employment and Social Policies in the Protectorate Bohemia and Moravia 19391945. Praha 2018, 91-102.

76 Cf. Przybylová/Šerka, Muži s mocí (cf. n. 70), 32-34. 
built by the mining and steel works in Karviná-Třinec in Lískovec u Místku, an area still under the jurisdiction of the Ostrava Oberlandrat.

\section{Plans in the Landscape and Rural Areas}

Even rural landscape and rural settlements were to play an important role in the German vision of transforming the space of Bohemia and Moravia. Various partial studies, plans, and models of 'ideal' landscapes corresponding to German ideals had been proposed. In practice, though, Germanisation in the territory of the Protectorate was implemented by the following three main methods: 1) transfer of share ownership, 2) so-called Aryanization of Jewish property, ${ }^{77}$ 3) settlement of Germans on the soil of Czech owners. This ranking more or less corresponds to the sequence in which these steps were taken. This was the general framework within which the intended transformation of architecture, city planning, and landscape was to take place. In other words, the broad framework outlined above included a visual element, an external reminder of the dominance of the German element. The transformation of towns in the spirit of architecture and urban planning imbued with national, Nazi-promoted style, not only resulted in a change of appearance: it was an external manifestation of a much deeper shift. The building of German schools, institutions, and associations were to be reassessed in terms of conformity to architectonic styles promoted in the Reich, but the change went further to the extent that even the layout of urban areas, and the organisation of rural areas, were to be radically transformed.

The effect of the law on the distribution of settlements (Wohnsiedlungsgesetz über Aufschließung von Wohnsiedlungen), adopted in September 1933, was extended to the Protectorate. It was favoured by Heinrich Himmler (1900-1945), Reich Commissioner for the Consolidation of German Nationhood (Reichskommissar für die Festigung des deutschen Volkstums), ${ }^{78}$ and helped the Nazi regime to implement regional and state-wide planning, both in Germany and in the occupied territories. Its extension to the Protectorate was based on Hitler's decision, on 7 October 1939, which granted Himmler the legal powers needed to implement this act in the occupied eastern territories.

Some of the most prominent projects to influence the landscape of Bohemia were the highways and bridges across the Vltava River. In terms of highways, Ger-

77 Cf. Jančík, Drahomír; Kubů, Eduard; Šouša, Jiří: Arisierungsgewinnler. Die Rolle der deutschen Banken bei der „Arisierung“ und Konfiskation jüdischer Vermögen im Protektorat Böhmen und Mähren (1939-1945). Wiesbaden 2011 (Studien zur Sozial- und Wirtschaftsgeschichte Ostmitteleuropas 21), 31-170.

78 On its importance, cf. Giaccaria, Paolo; Minca, Claudio (Ed.): Hitlers Geographies. The Spatialities of the Third Reich. London 2016, 183-184. 
many asserted its dominance not only in the development of a Reich highway linking Vienna, Brno, and Breslau (Wroctaw), but also by placing some of the foremost German experts in leading positions within the original Czechoslovak interwar project of an east-west highway linking Prague-Brno-Zlin. ${ }^{79}$ References to German architects Paul Bonatz, Fritz Lehmann from the German Technical University in Prague, Karl Fischer (1901-1948), Fritz Freising, and Walter Orliczek (b. 1900) from the German Technical University in Brno can be found in connection with highway construction in the Protectorate. ${ }^{80}$

German experts applied new trends not only to the construction of highways and bridges, but also to the integration of these technical constructions into the landscape. ${ }^{81}$ The Protectorate even became a testing ground for this new 'biodynamic' trend. ${ }^{82}$ Hans Lorenz (1900-1975) - Fritz Todt's (1891-1942) deputy for the preparation and construction of highways in the Protectorate - along with the wellknown garden designer Alwin Seifert (1890-1972), convinced Todt that this method should be implemented in the design of the Breslau-Brno-Vienna highway. ${ }^{83}$ It comprised a set of measures whose aim was to imbed the highway into the landscape as unobtrusively as possible. Where the body of the highway had to cut into the landscape, a larger area of the cut was preferred so as to achieve a smaller incline on the resulting slopes. Wherever possible, larger bridges were to be replaced by high embankments, which would subsequently be covered with greenery.

79 Cf. Lídl, Václav; Janda, Tomáš: Dálnice - ojedinělé technické dílo, které zmařila 2. světová válka' [Highways - A Unique Technical Feat Thwarted by the Second World War]. In: Hořejš, Miloš; Lorencová, Ivana (Ed.): Věda a technika v českých zemích v období 2. světové války [Science and Technology in the Czech Lands During WWII]. Praha 2009 (Práce z dějin techniky a př́rodních věd 20), 90-103, as well as Lídl, Václav: Silnice a dálnice v České republice. Vývoj stezek, cest, silnic a dálnic na našem území od nepaměti až po současnost [Roads and Highways in the Czech Republic. The Development of Paths, Tracks, Roads, and Highways in Our Territory from Time Immemorial until Today]. Rudná 2009, 45-63.

80 Cf. May, Roland: Pontifex Maximus. Der Architekt Paul Bonatz und die Brücken. Darmstadt 2011, 749.

81 For a general perspective, cf. Jäger, Wolfgang F.: Der Streckenentwurf der Reichsautobahnen 1933 bis 1945. Eine ingenieurtechnische Analyse auf der Grundlage ausgewählter Archivbestände. Köln 2013.

82 Cf. Zeller, Thomas: Driving Germany. The Landscape of the German Autobahn, 1930-1970. New York 2007.

83 For more on A. Seifert, cf. Reitsam, Charlotte: Das Konzept der „bodenständigen Gartenkunst“ Alwin Seiferts. Ein völkisch konservatives Leitbild von Ästhetik in der Landschaftsarchitektur und seine fachliche Rezeption bis heute. In: Gartenkunst 13/2 (2001), 275-303 and Falter, Reinhard: Alwin Seifert (1890-1972). Die Biographie des Naturschutzes im 20. Jahrhundert. In: Berichte der ANL 28 (2004), 69-104. 


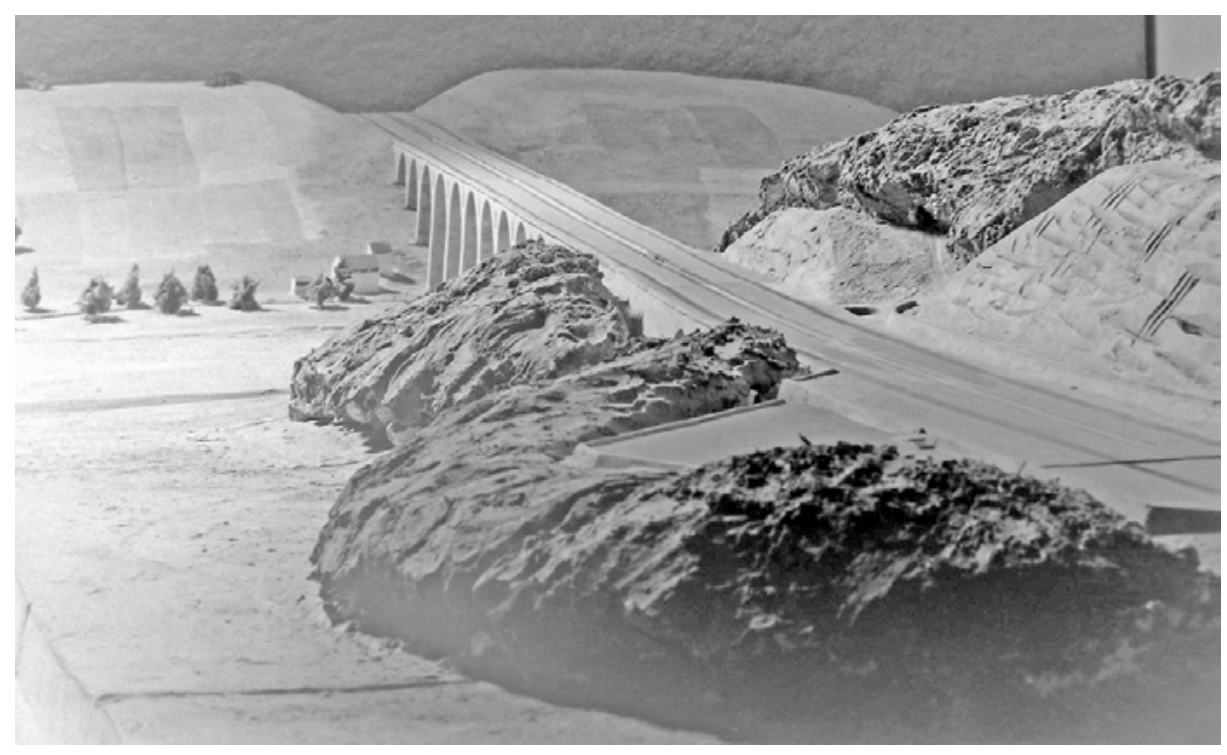

Fig. 5: Model of the Bridge for the Reich highway linking Vienna, Brno, and Wroctaw (Archive of Tomáš Janda).

At least some of the planned alterations around highways had been actually realised, as one can see in preserved contemporary photographs. Wild fruit or ornamental trees can be seen there up to this day, and some nurseries for useful plants were established in the suburbs of Brno. ${ }^{84}$ The role of Czech experts in these projects was minimal.

\section{Relics of Nazi Architecture in Spatial Context}

Specialised maps, those with additional content developed by experts in their fields, have been regarded as a respected research outcome in the Czech Republic for over a decade now. These are currently defined as an expression of information regarding particular localities, areas, spaces, or even times (4D) by cartographic methods or via a geographical information system (GIS). This information is presented with

84 Cf. Moravský zemský archiv [Moravian Provincial Archive] Brno. Coll. B40/III. I would like to thank Tomáš Janda for bringing these facts to my attention. For further detail, cf. Hořejš, Miloš: Pojetí městské zeleně a krajinotvorby v plánech německých urbanistů a architektů v Protektorátu Čechy a Morava - odborná východiska, praktické realizace' [The Concept of Urban Greenery and Landscape Creation in the Plans of German Urban Planners and Architects in the Protectorate Bohemia and Moravia]. In: Zámečník, Roman (Ed.): Zahradně-architektonická tvorba 20. století v Československu [Garden Architecture in Twentieth-Century Czechoslovakia], Praha 2019, 84-103. 
its context acquired based on the research of a particular area or 3D object. Specialised maps increasingly find their application in areas such as archaeology, heritage care, or the history of art. ${ }^{85}$ They have also found their niche in areas such as mapping the history of buildings and architecture, including industrial heritage. ${ }^{86}$ References to these results are available at websites of the maps' authors.

A fusion of expert information on a particular place in this manner enables the users of specialised maps not only to get better acquainted with particular objects or places using interactive links incorporated in the map, but also to find its location within an area more easily. Users of specialised maps can then, thanks to GIS coordinates, better find the object of interest and see it in situ.

We have recently been working in the National Technical Museum in Prague on such a specialised map pertaining to buildings which were either built or proposed but not constructed during the Nazi occupation of the Czech Lands. The map, at this point covering only the territory of former Protectorate of Bohemia and Moravia, is one of the outcomes of the institutional support for science and research provided by the Ministry of Culture of the Czech Republic.

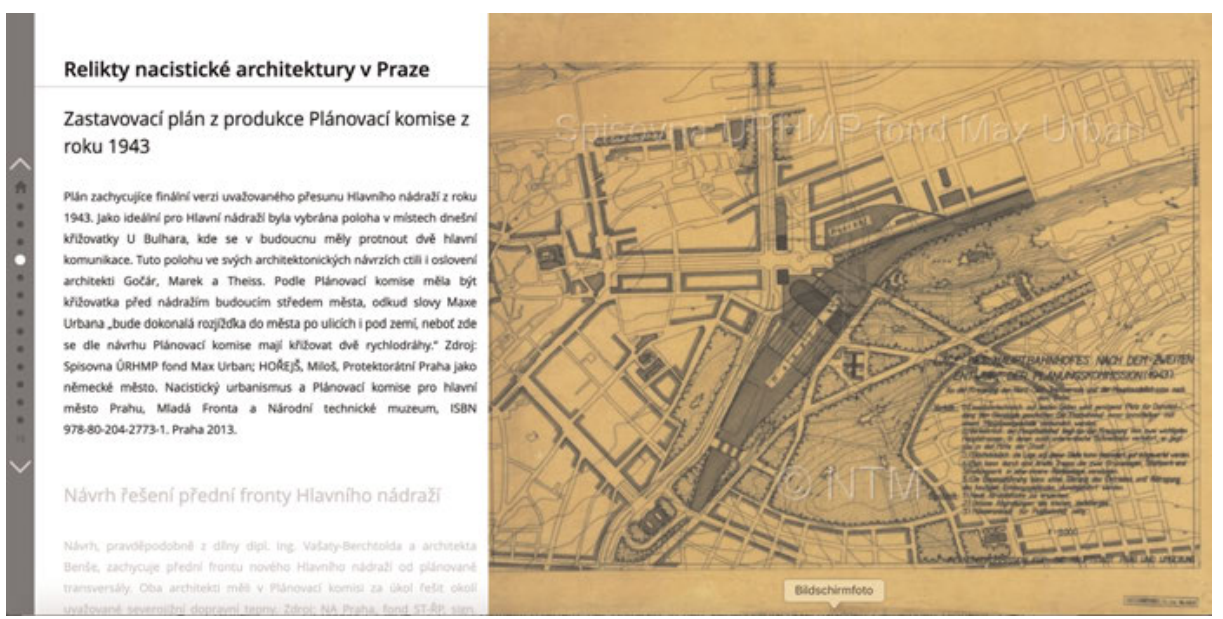

Fig. 6: Zastavovací plán z produkce Plánovací komise z roku 1943 [Building Plan Produced by the Planning Commission of 1943]. Screenshot of the GIS map "Relics of Nazi Architecture in Spatial Context" (URL: https://arcg.is/b5mbC2).

85 Cf. Národní památkový ústav [National Heritage Institute]: Výsledky vyhledávání [Search results]. URL: https://www.npu.cz/cs/vysledky-vyhledavani?query=Mapa\&section=\&type=Research (23.01.2021).

86 Cf. Výzkumné centrum průmyslového dědictví (VCPD) Fakulty architektury (FA) ČVUT v Praze [Research Centre for Industrial Heritage at the Faculty of Architecture of the Czech Technical University in Prague]: Industriální topografie. Průmyslová architektura a technické stavby [Industrial Topography. Industrial Architecture and Technical Buildings]. URL: http://www.industrialnitopo grafie.cz/ (23.01.2021). 
For each point of interest in the map, users will find not only its GPS but also a brief description with references to sources. Each such reference will also include images of current state of the object and, where possible, also period photographs. ${ }^{87}$ In the case of places where building was planned during the occupation but not realised, users will be able to view contemporary plans or visualisations and, where possible, georeferenced contemporary plans will enable, via the merging of levels of the map, a comparison with the current state of the location.

This electronic map with specialised content focused on relics of Nazi architecture should be, after a thorough review, placed on the website of the National Technical Museum, where it would be available to the general public. Similar past projects implemented in a similar manner worked well. The electronic map will also exist in a paper form, that is, as a book where the maps will be supplemented by longer texts and further images.

87 Due to copyright concerns, photographs will be available only in preview quality. 
